Bohumil VYKYPĚL

Ústav pro jazyk český AV ČR

Brno

vykypel@ujc.cas.cz
UDK 811.162.3’361

Pregledni rad

Primljen: 28. svibnja 2019.

Prihvaćen: 9. listopada 2019.

\title{
POTENCIÁLNÍ NELEXIKÁLNÍ PALEOSLOVENISMY VE STARÉ ČEŠTINĚ
}

V textu se probírají staročeské jazykové elementy z jiných oblastí než lexikum považované v literatuře za pocházející ze staroslověnštiny a zkoumá se, nakolik v nich skutečně můžeme spatřovat paleoslovenismy. Autor dochází k závěru, že do jisté míry pravděpodobný je staroslověnský původ jen u menšiny těchto prvků.

Klíčová slova: nelexikální paleoslovenismy, stará čeština, staroslověnština

\section{1. ÚVODNÍ POZNÁMKY}

Otázka vlivu staroslověnštiny na starou češtinu představuje jedno z velkých témat společných paleoslovenistice a paleobohemistice, ale také obecně jedno z velkých témat debat o české kulturní orientaci. Překvapuje prritom, že tato otázka dosud nebyla pojednána s důkladností úměrnou váze, která jí bývá přikládána. Zatímco pro oblast lexika nacházíme $\mathrm{v}$ literatuře alespoň různé korpusy paleoslovenismů, analyzované tu méně, tu více důkladně (srov. VYKYPĚL 2019), setkáváme se v jiných oblastech jazykového systému jen $\mathrm{s}$ jednotlivými nápady, rozptýlenými $\mathrm{v}$ literatuře $\mathrm{k}$ tématu. Na tomto místě tak chceme souhrnně probrat možné nelexikální paleoslovenismy ve staré češtině. Přitom chceme především podat jejich přehled jako východisko $\mathrm{k}$ prŕípadné další detailnější a materiálové práci.

* Text byl napsán s podporou grantového projektu Grantové agentury ČR č. 18-02702S Staroslověnské dědictví v staré češtinè. 


\section{SLOVOTVORBA}

Nezávisle na sobě vyslovili domněnku, že paleoslovenismus představuje staročeský sufix nomin agentis -tel, Helmut Keipert a Dušan Šlosar. Šlosar argumentoval různou distribucí tohoto sufixu a jeho staroslověnského protějšku: zatímco užití stsl. -tel'b není omezeno sémantikou fundujícího slovesa, tvoří se stč. -tel převážně odvozeniny od sloves označujících intelektuální děje (srov. ŠLOSAR 1982: 132-133; ŠLOSAR 1986: 257-259). Keipert takový výklad zarámoval do širšího slovanského kontextu, když na bohatém materiále ukázal, že také v ostatních slovanských jazycích mají odpovídající sufixy výrazně spisovnějazykovou povahu (srov. KEIPERT 1977). Etymologie slovanského sufixu -tel- bohužel není jasná, takže nelze s jistotou říct, zda jde o inovaci slovanského dialektu, který byl vzat za základ staroslověnštiny, rozšiřrenou pak k dalším slovanským jazykům, nebo se naopak jedná o archaismus uchovaný $\mathrm{v}$ řečeném dialektu, který pak skrze staroslověnštinu oživil a zproduktivněl tento sufix i v jiných slovanských jazycích (srov. k tomu VYKYPĚL 2017: 456-457). Nicméně domněnku, že stč. -tel pochází ze staroslověnštiny nebo byla jeho produktivita rozvinuta vlivem staroslověnštiny, můžeme považovat za pravděpodobnou.

Keipert pak ještě navíc dokazoval, že církevněslovanského původu je také stč. adjektivní sufix -telný, vyjadřující zejména potenciální zasažení dějem, protože také on i jeho protějšky ve slovanských jazycích mají výrazně spisovnějazykovou povahu (srov. KEIPERT 1977). Tento předpoklad je nicméně o něco méně jistý, než je tomu v př́ípadě sufixu -tel, protože staročeský formant a stsl. -telbnb se na rozdíl od stč. -tel a stsl. -tel'b nekryjí ani funkčně ani formálně. Ve funkčním ohledu jde předně o to, že ve staroslověnštině lze sotva mluvit o skutečném sufixu -telbnъ, protože útvary s tímto segmentem představují relační adjektiva odvozená sufixem -bnъ od nomin agentis na -tel'b a konstituce deverbativního sufixu -telbnъ spadá až do církevní slovanštiny mladších redakcí srbské, bulharské a ruské (srov. CEJTLIN 1977: 106; KEIPERT 1977 passim) a zrejmě také chorvatské (srov. REINHART 1986); podobně stč. -telný se pro vyjadřování potenciálního zasažení dějem specializuje až v průběhu historické doby. ${ }^{1}$ Ve formálním ohledu pak jde o to, že staročeský sufix má dvojí podobu, totiž -telný nebo -tedlný, což ukazuje na to, že při vzniku sufixu bylo využito různých stávajících formantů (srov. i GEBAUER

1 Srov. GEBAUER 1882; HAVRÁNEK 1963: 270-273; RUSÍNOVÁ; ŠLOSAR 1967: 46; RUSÍNOVÁ; ŠLOSAR 1967: 57-58; ŠLOSAR 1986: 308-312. 
1894: 409). Staročeský sufix a jeho protějšek ve zmíněných církevních slovanštinách se tak zjevně konstituovaly až $\mathrm{v}$ historické době a nezávisle na sobě. Přesto není nepředstavitelné, že jeden $\mathrm{z}$ komponentů tohoto konstitučního procesu ve staré češtině - nebo přesněji řečeno jeden z předhistorických kořenů tohoto procesu - snad tvořila »českocírkevněslovanská inspirace«, totiž to, že proces vzniku a funkčně-sémantické specifikace formantu -telbnъ zřejmě započal také v české církevní slovanštině (srov. KEIPERT 1977: 58-59).

Jako o možném paleoslovenismu lze uvažovat také o jiném staročeském slovotvorném prostředku - slovesném prefixu $z$-. Předpokládá se, že jeho praslovanský předchůdce, prefix *jbz-, ve svém prostorovém významu 'zevnitř ven' konkuroval prefixu * $v y$ - a tato konkurence byla v historické době proměněna $\mathrm{v}$ geografickou komplementární distribuci: $\mathrm{v}$ řečeném prostorovém významu se kontinuanty praslovanského ${ }^{*} j b z$ - uplatňují v jihoslovanských jazycích, zatímco kontinuanty praslovanského *vy- tak fungují v severoslovanských jazycích (srov. KOPEČNÝ 1973: 80-81; KOPEČNÝ 1973: 267-269). Implikací bychom pak mohli pokládat výskyt prostorového významu prefixu $z$ - v severoslovanské staré češtině za výsledek vlivu jihoslovanského konstitučního základu staroslověnštiny. To skutečně předpokládá pro českou církevní slovanštinu Vepřek, který zároveň ukazuje, že tento prefix byl v české církevní slovanštině dokonce produktivní, protože jsou jím tvořena i slovesa doložená pouze $\mathrm{v}$ českocírkevněslovanských památkách; na druhou stranu ale také upozorňuje, že řečený prefix mohl být $\mathrm{v}$ prostorovém významu v prehistorické době ještě produktivní i v (pra)češtině, přičemž zmíněné církevněslovanské bohemismy by potom naopak ukazovaly na tuto (pra)českou produktivitu (srov. VEPŘEK 2015). Můžeme si teoreticky představit, že staroslověnský vliv jednak zastavil úplný zánik našeho prefixu v češtině, jednak - protože šlo o vliv jazyka s intelektuálními funkcemi - u něho rozvinul abstraktní význam a nasměroval jej do funkce rezultativně-perfektivizační. Rozhodnout, jak pravděpodobná je tato představa, je ovšem z deskriptivního hlediska fatálně ztíženo tím, že historický vývoj byl ve staré češtině zastřen konkurencí a konfúzí prefixů s-, vz- a $z$ - (k ní srov. nověji VAJDLOVÁ 2013).

Mladenova uvažuje o staroslověnském vlivu ještě u nominálního prefixu bez-: rozvinutí jeho produktivity ve staré češtině bylo podle ní podpořeno staroslověnštinou, $\mathrm{v}$ níž byl tento slovotvorný prostředek zase podpořen kalkováním řeckých nominálních derivátů s prefixem do- (srov. MLADENOVA 1999: 128). Je zjevné, že sám prefix bez- je domácí, praslovanský (srov. i TRUBAČEV 1975: 10-13), na což ukazují mezi jiným také četná propria s prefixem Bez-; domněnka, že ve staré češtině byl rozvinut staroslověnským 
vlivem nebo také staroslověnským vlivem, je možná, ale nikoli nutná, zejména pak zohledníme-li, že bez- není žánrově exkluzivní a že můžeme také počítat s působením latinského privativního nominálního prefixu in-

Kromě toho Mladenova vyslovila také názor, že vůbec slovotvorný postup kompozice, ve staroslověnštině podpořený a rozvinutý řeckým vlivem, byl ve staré češtině podobně podpořen a rozvinut staroslověnským vlivem, protože zde má knižní či intelektuální charakter; připouští ovšem, že ověření takové úvahy by vyžadovalo detailnější analýzu materiálu (srov. MLADENOVA 1999: 130-137). Takovou analýzu podnikl shodou okolností současně s Mladenovou Šlosar, a jak se zdá, přestože se soustředil zejména na deskriptivní a vnitrojazykovou stránku věci, jeho závěry nepodporují domněnku o zásadnějším vlivu staroslověnštiny na starou češtinu v tomto bodě (srov. ŠLOSAR 1999). Obecně pak můžeme ještě uvést několik skutečností ukazujících, že předpoklad staroslověnského vlivu na kompozici ve staré češtině není nezbytný. Předně je třeba říct, že tvoření slov kompozicí $\mathrm{v}$ češtině staré i nové nemá charakter knižního nebo intelektuálního jazykového prostředku, což by eventuálně mohlo ukazovat na staroslověnský vliv, nýbrž představuje prostě jen specifický prostředek, který je pro svou zvýšenou popisnost vhodný pro oblasti jako onymie, terminologie nebo expresivní vyjadřování. Dále musíme zohlednit, že - jak je všeobecně známo - stará i nová čeština byly v intenzivním kontaktu s jiným jazykem, v němž je kompozice častá, totiž němčinou. Konečně je v souvislosti se zmíněným uplatněním kompozice ve specifických oblastech slovní zásoby třeba poznamenat, že podobně se kompozice uplatňuje i v latině, jazyce jinak kompozitům spišs nepřejícím, s níž - jak je rovněž všeobecně známo - byly stará i nová čeština také v intenzivním kontaktu. Nicméně můžeme i přes tyto skutečnosti připustit, že vliv staroslověnštiny nebo české církevní slovanštiny je jako jeden z faktorů rozvoje slovotvorného postupu kompozice ve staré češtině možný nebo spíš není vyloučený, byt' je zřejmě třeba jej chápat jako faktor spíš podpưrný než iniciující.

Zjevně nepravděpodobný je naopak vliv staroslověnštiny na užití stč. komparativu v superlativní funkci, jak jej naznačoval Vondrák (srov. VONDRÁK 1893: 17; VONDRÁK 1895: 307-308) a podle něho i Mladenova (srov. MLADENOVA 1999: 124). Už Flajšhans poznamenal, že superlativ se v češtině i $\mathrm{v}$ jiných slovanských jazycích gramatikalizuje až během historické doby. ${ }^{2}$

2 Srov. FLAJŠHANS 1895: 492 a obecně i GEBAUER 1929: 210 a VAILLANT 1958: 593-595. 


\section{SYNTAX}

Sreznevskij měl za možné, že paleoslovenismem je staročeský dativ absolutní (srov. SREZNEVSKIJ 1850: 88; SREZNEVSKIJ 1887: 71). Podobně se vyjádřil Vondrák: protože je podle něho dativ absolutní ve staré češtině rrídký a omezený na evangelní a príbuzné texty, je třeba prripsat jeho výskyt především církevněslovanskému vlivu; prritom ovšem samu konstrukci dativu absolutního měl Vondrák za praslovanskou, ale ve staré češtině mezitím už zaniklou a oživenou až církevní slovanštinou (srov. VONDRÁK 1893: 30-31; VONDRÁK 1893: 35-36). Stanislav Vondrákovu domněnku připouští, ale její potvrzení nechává až budoucímu bádání (srov. STANISLAV 1933-1934: 42). Vondrákovi naopak oponoval Flajšhans, který stč. dativ absolutní označil jako »hrubý latinismus«, vzniklý tím, že latinský ablativ, v plurálu synkretizovaný s dativem, byl pochopen jako dativ a dativem přeložen (srov. FLAJŠHANS 1894.a: 375; podobně VINTR 1977: 46). Flajšhansovi zase oponoval Kvíčala, který se ptal, jak se dativ absolutní, je-li to latinismus, dostal do staroslověnských textů (srov. KVÍČCALA 1895: 85). Na to konečně Flajšhans odpověděl jednak tím, že zdůraznil, že vyloží-li se stč. dativ absolutní jako latinismus, neznamená to, že latinismem je i stsl. dativ absolutní, jednak tím, že poukázal na to, že dativ absolutní není ve staré češtině doložen ve starších a originálních památkách, ale jen tam, kde jde zjevně o omyl překladatele (srov. FLAJŠHANS 1894.b: 467). O neobratném překládání z latiny tu mluví i Gebauer (srov. GEBAUER 1929: 397) a podobně se vyjádřil Večerka, když staročeské absolutní konstrukce s dativem, ale také s instrumentálem a genitivem (k těm srov. GEBAUER 1929: 367; GEBAUER 1929: 421), označil za umělé ad hoc pokusy o nalezení ekvivalentu latinského ablativu absolutního (srov. VEČERKA 1996: 189). Z pozitivní, nepreskriptivní perspektivy pak můžeme stč. dativ absolutní vyložit i jako snahu o ozvláštnění jazyka užitím nápodoby »učené« latinské konstrukce. V každém př́ípadě je nejspíš jednodušší konstrukce s dativem absolutním vysvětlovat bez domněnky o staroslověnském vlivu.

Vondrák ${ }^{3}$ - a nesměleji i Menčík ${ }^{4}$ - naznačoval vliv staroslověnštiny také na stč. konstrukce s adnominálním dativem, když měl obraty skřehot zubóm, věky věkóm nebo podnož nohám tvým za ovlivněné církevněslovanským tex-

3 Srov. VONDRÁK 1893: 14-15; VONDRÁK 1893: 19-20; VONDRÁK 1893: 35; VONDRÁK 1895: 309; VONDRÁK 1908: 365; VONDRÁK 1928: 264.

4 Srov. MENČÍK 1893: XXV. 
tem či reminiscence $\mathrm{z}$ církevní slovanštiny; ${ }^{5}$ podobně zde nověji Vepřek má vliv staroslověnštiny za možný, přinejmenším pokud jde o tradování ustálených spojení jako věky věkóm nebo otpuščenie hřiechóm, charakteristických pro »biblický jazyk« (srov. VEPŘEK 2018). Nicméně se zdá, že adnominální dativ je ve staré češtině sice archaický, ale textově neexkluzivní; ${ }^{6}$ staroslověnský vliv snad lze připustit jen jako vliv na delší udržení staré domácí konstrukce nebo na replikaci ustálených spojení s touto konstrukcí.

Na pomezí syntaxe a lexikonu patří otázka výběru pádu do staročeského obratu ve jmě, ve jmeno 've jménu'. Kvíčala vyložil překlad $u$ mé jmě v evangeliáři Vídeňském (Mt 18,20) jako paleoslovenismus, argumentuje tím, že akuzativní formu pro latinský ablativ in nomine meo nelze vysvětlit jinak než

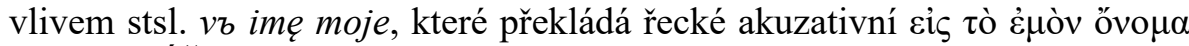
(srov. KVÍČALA 1895: 80-81). Vondrák to rozšíríil na obrat ve jmě, ve jmeno vůbec, prohlásiv, že se může jednat o »zdomácnělé rčení«, tedy o vliv nejen textový, ale i jazykový (srov. VONDRÁK 1895: 311). Jakubec tuto shodu mezi starou češtinou a staroslověnštinou pak dokonce označil za nepochybnou (srov. JAKUBEC 1929: 39) a staroslověnský vliv zde připouštěla i Mladenova (srov. MLADENOVA 1999: 124). Naopak Flajšhans rozhodně popíral, že by ve jmě bylo stopou staroslověnského textového vlivu na stč. evangelní překlad, protože je to obrat ve staré češtině hojně rozšířený a textově neexkluzivní, ${ }^{7}$ ale otázku, zda jde o staroslověnský vliv jazykový, nechává otevřenou, poukazuje jen implicite na obecnou skutečnost, že pádové formy nereflektují vztahy mezi mimojazykovými entitami, ale představují konvenční jazykové stylizace těchto vztahů, a proto ani nelze apriori očekávat shodu pádových forem v různých jazycích (srov. FLAJŠHANS 1894.b: 465-466; FLAJŠHANS 1895: 495). Pak nás nemusí překvapit rozdíl mezi stč. ve jmě a latinským in nomine a není ani třeba hledat pro něj vysvětlení (např́íklad ve vlivu staroslověnštiny). Nicméně i přes tuto přijatelnou vysokou teorii můžeme poukázat na to, že konkrétně tento obrat, byt' i rozšířený, má svůj počátek v náboženské formuli, a tedy nejspíš ve starém domácím liturgickém jazyce staroslověnštině.

\footnotetext{
5 Vondrák tak změnil své starší mínění (srov. VONDRÁK 1892: 61). V př́ípadě obratu skřehot zubóm s ním souhlasil i Flajšhans (srov. FLAJŠHANS 1903: 27, pozn. 1).

6 Srov. GEBAUER 1929: 395-396; VINTR 1977: 96.

7 K tomu srov. i GEBAUER 1903: 660; GEBAUER 1903: 662.
} 


\section{DALŠÍ OBLASTI}

Uvažovat lze také o tom, zda se za tím, že duál a jednoduché minulé časy aorist a imperfektum představují ve staré češtině - zejména ve srovnání se starou polštinou - celkem živé kategorie, neskrývá rovněž staroslověnský vliv (srov. VYKYPĚLOVÁ 2014: 8-9). Proti takové domněnce sice hovoří areálový kontext, totiž uchování duálu a jednoduchých minulých časů v lužické srbštině. Na druhou stranu je třeba uvážit, že lužická srbština se nacházela v jiném kontextu kontaktovém, když její kontakt s němčinou byl relativně silnější než v př́padě češtiny, at' už $\mathrm{s}$ efektem divergentním jako v prrípadě duálu, nebo konvergentním jako $\mathrm{v}$ př́ípadě jednoduchých minulých časů.

V oblasti formální morfologie pak hledala Karpluk staroslověnský vliv v různé morfologické adaptaci řecko-latinských maskulinních $a$-kmenových osobních jmen: zatímco jejich přiřazení ke stč. $a$-kmenové deklinaci (typ Juda, Tóma < Iov́ $\delta \alpha \varsigma /$ Iudas, $\Theta \omega \mu \tilde{\alpha} \varsigma /$ Thomas) představuje podle ní způsob adaptace přejatý ze staroslověnštiny, je přrirazení ke stč. jo-kmenové deklinaci (typ Tomášs, Judáś) pozdější, reflektující přejetí z latiny (srov. KARPLUK 2010: 252-258); souhlasila s ní Mladenova (srov. MLADENOVA 1999: 138). Podobně spatřovaly Karpluk a Mladenova staroslověnský vliv v různé morfologické adaptaci řecko-latinských maskulinních osobních jmen na -los/-ius,

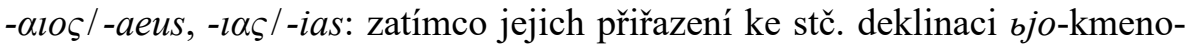

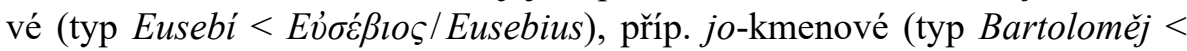

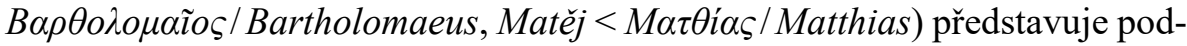
le nich způsob adaptace přejatý ze staroslověnštiny, jsou stč. jo-kmenové formy končící na -š (typ Eusebiáš, Matúš) pozdější, reflektující přejetí z latiny (srov. KARPLUK 2010: 272-285; MLADENOVA 1999: 137-138). Zdá se ale, že v obou případech je jednodušší vysvětlení vnitrojazykové: bud' jako kmen zobecněl tvar nominativu, nebo zobecněl kmen nepř́mých pádů. ${ }^{8} \mathrm{Na}-$ nejvýš snad lze připustit, že různý způsob adaptace řecko-latinského jména nacházel rozdílnou jazykověkontaktovou podporu: adaptace založená na nominativu v němčině, jak by dosvědčovalo i $\check{s}$ za $s$, adaptace založená na nepř́mých pádech pak ve staroslověnštině. Proti vlivu staroslověnštiny přitom ovšem mluví to, že typ Eusebi, Matěj není textově nebo stylově exkluzivní.

Karpluk postulovala v oblasti staročeských osobních jmen ještě jednu adaptaci jako výsledek staroslověnského vlivu, a to způsob fonologické

8 Obecně ke značně kolísající morfologické adaptaci řecko-latinských jmen ve staré češtině srov. GEBAUER 1896: 564-573. 
adaptace řecké, resp. řecko-latinské sekvence $\mathrm{V} v \mathrm{~K} / \mathrm{V} u \mathrm{~K}$. Ve staroslověnštině byla tato sekvence adaptována pomocí sekvence VvbK/VvbK (srov. KARPLUK 2010: 259-265; KARPLUK 2010: 286-296). Přímý odraz tohoto způsobu fonologické adaptace představuje podle autorky stč. Pavel, tedy kon-

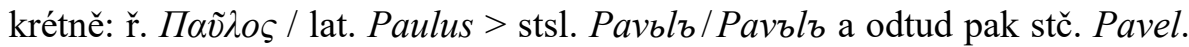
V jistém smyslu překrytý odraz řečené adaptace pak autorka spatřuje ve stč. Šavel: zatímco $\breve{S}$ - je novější z němčiny, příp. dobové latiny, jsou - $a v$ - a pohyblivé $e$ archaické, reflektujíce staroslověnský vzor (tedy stsl. Savblъ /Savъlъ < ř. $\Sigma \alpha \tilde{v} \lambda o \varsigma /$ lat. Saulus). Konečně odraz nepř́mý, tj. zprostředkovaný jménem Pavel, představuje podle Karplukové Havel ( $<$ středolat. *Gaulus), bez protějšku ve staroslověnštině, a Vavřinec (středolat. Laurentius), jen s nepř́ímým staroslověnským protějškem, totiž stsl. Lavrentii (srov. KURZ 1973: 103). Zdá se ale, že jednodušší je vysvětlovat stč. Pavel bez předpokladu staroslověnského vlivu jako výsledek staročeské či pračeské fonologické adaptace neobvyklé (cizí) finální sekvence -Vul: lat. Paulus $>$ pračeské $*$ Paut $\rightarrow$ (adaptace pomocí vkladného pohyblivého e) *Pauet > stč. Pavel. Totéž pak mutatis mutandis platí pro stč. Šavel a Havel. V prvním případě to platí bez obtíží: lat. Saulus [Šauluš] > pračeské * Šaut $\rightarrow$ (adaptace pomocí vkladného pohyblivého $e) *$ Śauet $>$ stč. Šavel. V druhém př́ípadě pak menší obtíže činí latinský zdroj přjetí, a průběh adaptace tohoto jména tak má dvě možné verze: (1) lat. Gallus $>$ pračeské ${ }^{*}$ Gatt $>*$ Gaut $\rightarrow$ (adaptace pomocí vkladného pohyblivého $e$ ) *Gauet > stč. Havel (srov. GEBAUER 1903: 408); (2) středolatinské variantní *Gaulus (k němu srov. KARPLUK 2010: 289-290) $>$ pračeské ${ }^{*}$ Gaut $\rightarrow($ adaptace pomocí vkladného pohyblivého e $){ }^{*}$ Gauet $>$ stč. Havel. Pokud jde konečně o stč. Vavřinec, počátek tohoto jména lze beze všech obtíží odvodit př́mo z jeho latinského protějšku: lat. Laurentius $>$ pračeské *Laur'- > *Uরaur'- > stč. Vav̌r-.

Konečně jeden nápad z oblasti ortografie čteme $\mathrm{v}$ dopise Trubeckého Jakobsonovi z 24. 9.1935 (srov. JAKOBSON 1975: 348-349). Trubeckoj píše o diakritických znacích v Kyjevských listech a mimo jiné říká, že je zajímavé, že oblouček jako znak vokalické délky, který nacházíme právě v Kyjevských listech, u jižních Slovanů zcela zmizel, zatímco se zdá, že u Čechů se udržel do 14. století, kdy jej nacházíme v apokryfech z počátku 14. století (legenda o Jidášovi, legenda o apoštolích, legenda o Pilátovi aj.), dodávaje, že by to mluvilo ve prospěch Jakobsonovy teorie o životnosti cyrilometodějské tradice v českých zemích. Sám ale míní, že by na druhou stranu bylo velmi nepravděpodobné, že by se stopa hlaholského označení délky uchovala právě ve skupině památek, které jinak mají tak výraznou německou ortografii. Nápad 
spojit oblouček v Kyjevských listech a v nejstarších staročeských veršovaných legendách je skutečně značně odvážný (a dokonce ani sám Jakobson, jinak odvážných nápadů se nelekající, se ho, pokud víme, neujal). Platí také Trubeckého poukaz na výraznou německou inspiraci v ortografii zmíněných památek (srov. k ní VYKYPĚLOVÁ 2014: 16; VYKYPĚLOVÁ 2014: 18-22). Nicméně původ staročeského obloučku značícího délku vyjasněn není, a proto zde Trubeckého myšlenku ponechme zaznamenanou pro budoucí badatele.

\section{DNY V TÝDNU}

Nakonec zmiňme ještě jeden možný vliv staroslověnštiny na pomezí lexikonu a gramatiky ve smyslu strukturace jazykového systému, totiž pojmenování dní v týdnu.

Můžeme etymologicky vykládat jednotlivá slova pro dny v týdnu a pritom si můžeme také klást otázku, zda konkrétní staročeské názvy dní v týdnu nepocházejí ze staroslověnštiny. Můžeme si ale také položit otázku po vzniku a motivaci celého systému pojmenování dní v týdnu. V tomto ohledu je pak zejména nápadné, že - až na dvě výjimky, o nichž níže - je ve všech slovanských jazycích princip pojmenování dní v týdnu stejný: nepracovní den - den po nepracovním dni - 2. den (po nepracovním dni) - den uprostřed týdne - 4 . den (po nepracovním dni) - 5. den (po nepracovním dni) - přejetí hebrejského šabbāt. Tuto pozoruhodnou shodu a tento systém, který nemá obdobu jinde, vysvětloval Moszyński tak, že jde o výsledek intelektuálního činu jednotlivce, který užil existujících termínů různého původu a vytvořil z nich jeden konsekventní a originální systém; tímto tvůrcem byl podle Moszyńského sv. Metoděj (srov. MOSZYŃSKI 1985). Dodejme, že na to, že oním tvůrcem byl praktik a biskup Metoděj, a ne filozof Konstantin, by ukazovalo také to, že tento intelektuální čin se týkal organizační praxe, ne teologické teorie.

Jiní ovšem hledají původ principu, na němž je vystavěn celek slovanského pojmenování dní v týdnu, jinde. Mareš zde spatřoval furlánský vliv, ukazující na činnost misie akvilejského patriarchátu, ale blíže to nerozvedl (srov. MAREŠ 1962: 515-516). Předcyrilometodějské kořeny pak předpokládá i řada dalších badatelů (srov. MATUSZEWSKI 1978: 122-127). Přiznejme, že domněnka o velkém intelektuálním činu sv. Metoděje je přece jen trochu romantická. Nicméně skutečně zaráží zmíněná celoslovanská shoda, která by byla nejsnáze vysvětlitelná tím, že daný systém pojmenování se rozšiřil skrze staroslověnštinu. $V$ tomto ohledu pak je, jak myslíme, významná druhá z výše 
ohlášených výjimek. Výjimka první, ruské voskresen 'je 'neděle', představuje pozdější církevní slavismus, který vytlačil starší nedělja (srov. ANIKIN 2014: 291), ale výjimka polabská je relevantní: polabské skopě 'pátek', tedy původně 'skoupý, chudý, tj. postní, den', je sice zjevně pozdní, přičemž ovšem není jasné, jaký název toto slovo nahradilo, ale naopak polabské perěndan 'čtvrtek', tedy původně 'Perunův den', je zřejmě staré (srov. LEHR-SPŁAWIŃSKI; POLAŃSKI 1962-1994: 502-503; LEHR-SPŁAWIŃSKI; POLAŃSKI 1962-1994: 717); to se zdá ukazovat na to, že polabský celek pojmenování dní v týdnu byl vytvořen samostatně. Uvážíme-li relativně pozdní christianizaci polabských Slovanů a malou pravděpodobnost vlivu staroslověnštiny u nich, pak by to byl určitý, byt' snad ne definitivní, argument pro to, že »obvyklý« slovanský týdenní systém byl skutečně rozšířen staroslověnštinou.

\section{ZAVĚREČNÉ POZNÁMKY}

Pokusíme-li se nyní stručně (a mírně schematicky) vyhodnotit soubor potenciálních paleoslovenismů zkoumaných v předchozích oddílech, vidíme, že je možno jej rozdělit do několika skupin. První skupina zahrnuje elementy, které můžeme stěží považovat za paleoslovenismy (komparativ ve funkci superlativu, dativ absolutní, adaptace $\mathrm{V} v \mathrm{~K} / \mathrm{V} u \mathrm{~K}$, oblouček jako znak délky). Druhou skupinu tvoří prvky, jejichž staroslověnský původ je jednou z možností. Tuto skupinu můžeme nadto ještě strukturovat co do záběru či síly staroslověnského vlivu prostředkovaného daným elementem: jde pouze o vliv na oživení či funkční rozvinutí domácího archaismu nebo periferního elementu (z-, bez-, kompozice, adnominální dativ, duál, jednoduché minulé časy); jde o přejetí, ale daný element je více méně periferní (ve jmě, morfologická adaptace osobních jmen); jde o přejetí a daný element je více méně běžný (-telný, týden). Konečně v poslední skupině je jeden prvek, jehož staroslověnský původ je více méně jistý, přičemž co do síly staroslověnského vlivu jde o prvek více méně běžný (-tel).

Ve světle naší analýzy se vliv staroslověnštiny na nelexikální oblasti staré češtiny jeví jako slabý. To jako by potvrzovalo Trubeckého charakteristiku české staroslověnské tradice jako reliktní, ne progresivní (srov. JAKOBSON 1975: 327). Jakousi výjimkou z této reliktnosti by pak snad mohl být pokus o tvưrčí užití možná stylisticky př́znakového paleoslovenismu -tel v Kunhutině modlitbě z konce 13. století, kde, jak známo, nacházíme sérii ozvláštňujících neologismů s tímto sufixem (srov. k tomu VYKYPĚLOVÁ 2014: 10). Mož- 
ná, že je trefná charakteristika staroslověnského, př́ípadně obecněji cyrilometodějského dědictví v českém prostředí jako »fragmentární tradice«, s níž se vede dialog (nebo polemika) (srov. HLAVÁČEK 2016: 26).

\section{LITERATURA}

ANIKIN, A. E. 2014. Russkij ètimologičeskij slovar', 8. Moskva: Institut russkogo jazyka im. V. V. Vinogradova RAN.

CEJTLIN, R. M. 1977. Leksika staroslavjanskogo jazyka. Moskva: Nauka.

FLAJŠHANS, V. 1894.a. Vliv literatury staroslovenské na staročeskou. Listy filologické 21: $372-378$.

FLAJŠHANS, V. 1894.b. Vliv literatury staroslovenské na staročeskou II. Listy filologické 21: 463-469.

FLAJŠHANS, V. 1895. K otázce o vlivu církevní slovanštiny na starou češtinu. Časopis Musea Království českého 69: 487-498.

FLAJŠHANS, V. 1903. Nejstarši památky jazyka i písemnictví českého, I: Prolegomena a texty. Praha: Dr. Frant. Bačkovský.

GEBAUER, J. 1882. Př́pona -telný, -tedlný a význam -bilis. Listy filologické 9: 118-120.

GEBAUER, J. 1894. Historická mluvnice jazyka českého, I: Hláskosloví. Praha - Vídeň: F. Tempský.

GEBAUER, J. 1896. Historická mluvnice jazyka českého, III: Tvarosloví, I. skloňování. Praha - Vídeň: F. Tempský.

GEBAUER, J. 1903. Slovník staročeský, I: A-J. Praha: Unie.

GEBAUER, J. 1929. Historická mluvnice jazyka českého, IV: Skladba. Ed. F. Trávníček. Praha: Česká akademie věd a umění.

HAVRÁNEK, B. 1963. Studie o spisovném jazyce. Praha: Nakladatelství Československé akademie věd.

HLAVÁČEK, P. 2016. Češi v soukolí západo-východního dilematu. P. Hlaváček, V. Bělohradský, M. C. Putna, M. Romancov et al. Proč jsme Západ? Česko, Evropa a Západ mezi minulostí a budoucností. Praha: Filozofická fakulta UK, 19-84.

JAKOBSON, R. (ed.). 1975. N. S. Trubetzkoy's Letters and Notes. The Hague - Paris: Mouton.

JAKUBEC, J. 1929. Dějiny literatury české, I: Od nejstarších dob do probuzení politického. 2. vyd. Praha: Jan Laichter.

KARPLUK, M. 2010. Staropolskie studia językoznawcze. Kraków: Polska Akademia Umiejętności.

KEIPERT, H. 1977. Die Adjektive auf-telbnъ. Studien zu einem kirchenslavischen Wortbildungstyp I. Wiesbaden: Otto Harrassowitz.

KOPEČNÝ, F. 1973. Etymologický slovník slovanských jazyků. Slova gramatická a zájmena, I: predložky, koncové partikule. Praha: Academia.

KURZ, J. (ed.). 1973. Slovnik jazyka staroslověnského, II: K - O. Praha: Academia. 
KVÍČALA, J. 1895. Recenze: W. Vondrák: Die Spuren der altkirchenslavischen Evangelienübersetzung in der altböhmischen Literatur (Wien 1893). České museum filologické 1: 77-87.

LEHR-SPŁAWIŃSKI, T.; K. POLAŃSKI. 1962-1994. Stownik etymologiczny języka Drzewian połabskich. Wrocław etc.: Wydawnictwo PAN etc.

MAREŠ, F. V. 1962. České prvky v polabské slovní zásobě. Slavia 31: 513-523.

MATUSZEWSKI, J. 1978. Słowiański tydzień. Geneza, struktura i nomenklatura. Łódź: Ossolineum.

MENČÍK, F. (ed.). 1893. Dva evangelistáře. Praha: nákladem vlastním.

MLADENOVA, M. 1999. Kirilo-Metodieva geografija i ezikova istorija ili zapadnite slavjani, Kiril i Metodij i kakvo e (o)stanalo posle. Sofija: Cheron Pres.

MOSZYŃSKI, L. 1985. Kto i kiedy ustalił słowiańskie nazwy dni tygodnia. J. Reinhart (ed.). Litterae Slavicae medii aevi Francisco Venceslao Mareš sexagenario oblatae. München: Otto Sagner, 223-230.

REINHART, J. 1986. Über den Ursprung des adjektivischen Wortbildungstypus -telbnb im Kroatisch-Kirchenslavischen. Wiener Slavistisches Jahrbuch 32: 65-70.

RUSÍNOVÁ, Z.; D. ŠLOSAR. 1967. Průřrez vývojem slovotvorné soustavy adjektiv v češtině. Sbornik praci filosofické fakulty brněnské university A 15: 37-64.

SREZNEVSKIJ, I. 1850. Mysli ob istorii russkago jazyka. St. Peterburg: v tipografii voenno-učebnych zavedenij.

SREZNEVSKIJ, I. I. 1887. Mysli ob istorii russkago jazyka i drugich slavjanskich narečij. St. Peterburg: V. S. Balašev.

STANISLAV, J. 1933-1934. Datív absolutný v starej cirkevnej slovančine. Byzantinoslavica 5: $1-112$.

ŠLOSAR, D. 1982. Vývoj deverbálních substantiv s konkrétním významem v češtině. Sbornik praci filozofické fakulty brněnské univerzity A 30: 131-142.

ŠLOSAR, D. 1986: Slovotvorba. A. Lamprecht; D. Šlosar; J. Bauer. Historická mluvnice češtiny. Praha: Státní pedagogické nakladatelství, 251-340.

ŠLOSAR, D. 1999: Česká kompozita diachronně. Brno: Masarykova univerzita.

TRUBAČEV, O. N. 1975. Ėtimologičeskij slovar' slavjanskich jazykov. Praslavjanskij leksičeskij fond, 2: *bez - *bratrb. Moskva: Nauka.

VAILLANT, A. 1958. Grammaire comparée des langues slaves, II: Morphologie. Lyon: IAC.

VAJDLOVÁ, M. 2013. Ke konkurenci předpon $s_{-}^{-}, z-, v z-$ (nejen) ve staré a střední češtině. Slovo a slovesnost 74: 269-278.

VEČERKA, R. 1996. Altkirchenslavische (altbulgarische) Syntax, III: Die Satztypen: Der einfache Satz. Freiburg i. Br.: Weiher.

VEPŘEK, M. 2015. Prefix *(j)bz- as a component of lexical Bohemisms in Church Slavonic? I. Janyšková; H. Karlíková (ed.). Etymological Research into Old Church Slavonic: Proceedings of the Etymological Symposium Brno 2014, 9-11 September 2014, Brno. Praha: Lidové noviny, 423-430.

VEPŘEK, M. 2018. K adnominálnímu dativu ve staroslověnštině a staré češtině. P. Malčík (ed.). Vesper Slavicus. Sborník k nedožitým devadesátinám prof. Radoslava Večerky. Praha: Lidové noviny, 203-211. 
VINTR, J. 1977. Die ältesten tschechischen Evangeliare. Edition, Text- und Sprachanalyse. München: Otto Sagner.

VONDRÁK, W. 1892. Zur Würdigung der altslovenischen Wenzelslegende und der Legende vom heil. Prokop. Sitzungsberichte der Philosophisch-historischen Classe der Kaiserlichen Akademie der Wissenschaften, 127/13. Wien: F. Tempsky.

VONDRÁK, W. 1893. Die Spuren der altkirchenslavischen Evangelienübersetzung in der altböhmischen Literatur. Sitzungsberichte der Philosophisch-historischen Classe der Kaiserlichen Akademie der Wissenschaften, 129/10. Wien: F. Tempsky.

VONDRÁK, V. 1895. K otázce o vlivu církevní slovanštiny na starou češtinu. Časopis Musea Království českého 69: 301-314.

VONDRÁK, W. 1908. Vergleichende Slavische Grammatik, II: Formenlehre und Syntax. Göttingen: Vandenhoeck und Ruprecht.

VONDRÁK, W. 1928. Vergleichende Slavische Grammatik, II: Formenlehre und Syntax. 2. Aufl. von O. Grünenthal. Göttingen: Vandenhoeck und Ruprecht.

VYKYPĚL, B. 2017. Marginalia etymologica Bohemica. I. Janyšková; H. Karlíková; V. Boček (ed.). Etymological Research into Czech: Proceedings of the Etymological Symposium Brno 2017, 12-14 September 2017, Brno. Praha: Lidové noviny, 455-458.

VYKYPĚL, B. 2019. Staroslověnské dědictví ve staré češtině. E. Rusinová (ed.). Přednášky a besedy z LII. ročníku Letni školy slovanských (bohemistických) studii. Brno: Masarykova univerzita, 302-312.

VYKYPĚLOVÁ, T. 2014. Sechs Beiträge zur Geschichte des Tschechischen. München: LINCOM Europa.

\author{
S ažet a k \\ Bohumil Vykypěl \\ POTENCIJALNI NELEKSIČKI PALEOSLAVIZMI U \\ STAROČEŠKOME JEZIKU
}

Rad se bavi staročeškim jezičnim elementima koji ne pripadaju leksiku, a smatraju se posuđenicama iz crkvenoslavenskog, pri čemu se istražuje u kojoj ih je mjeri uistinu moguće smatrati paleoslavizmima. Razmatrani se elementi odnose na tvorbu riječi (sufiksi -tel i -telný, prefiksi $z$ - i bez-, složenice, komparativ sa značenjem superlativa), sintaksu (dativ apsolutni, adnominalni dativ, akuzativ umjesto lokativa u izrazu ve jmě 'in nomine'), morfologiju (sintetska prošla vremena, dvojina, morfološka adaptacija grčkih i latinskih imena), te na fonologiju i pravopis (grčko-latinski fonemski niz $V u K$, kvačica kao oznaka samoglasničke duljine). Povrh toga se istražuje i fenomen na granici gramatike (u smislu strukturiranja jezičnog sistema) i leksika - sustav nazivanja danā u tjednu. Autor dolazi do zaključka da bi jedino agentivni sufiks 
-tel mogao biti crkvenoslavenskoga podrijetla. Moguće, ali ne i naročito vjerojatno jest crkvenoslavensko podrijetlo u slučaju -telný, z-, bez-, složenicā, adnominalnog dativa, akuzativa u ve jmě, morfološke adaptacije imenā, prošlih vremena, dvojine i naziva danā u tjednu.

Ključne riječi: neleksički paleoslavizmi, staročeški, starocrkvenoslavenski

Preveo: Siniša Habijanec

\title{
Sum mary
}

\section{Bohumil Vykypěl \\ POTENTIAL NONLEXICAL PALEOSLOVENISMS IN OLD CZECH}

The present paper deals with Old Czech linguistic elements from other parts of the language system than the lexicon which have been regarded as borrowed from Old Church Slavonic: it is examined to what extent we really can consider them palaeoslovenisms. The elements in question belong to word-formation (suffixes -tel and -telný, prefixes $z$ - and bez-, composition, superlative meaning of comparative), syntax (dativus absolutus, adnominal dative, accusative instead of locative in ve jmě 'in nomine'), morphology (simple past voices, dual number, morphological adaptation of Greek and Latin names) as well as phonology and orthography (Greek-Latin phoneme sequence $V u C$, breve as vowel length mark). Also investigated is the system of naming the days of the week, a phenomenon on the borderline between grammar (in the sense of the structuring of the language system) and the lexicon. The author concludes that only the agentive suffix -tel may be viewed with some probability as being of Old Church Slavonic origin. Possible, but not very probable is the Old Church Slavonic origin in the case of -telny', z-, bez-, the compounds, the adnominal dative, the accusative in ve jmě, the morphological adaptation of names, the past tenses, the dual and the names of the days in the week.

Keywords: nonlexical palaeoslovenisms, Old Czech, Old Church Slavonic

\author{
Bohumil Vykypěl \\ Czech Language Institute of the CAS \\ Brno (Czech Republic) \\ vykypel@ujc.cas.cz
}

